\title{
A study on effects of the best human resource management methods on employee performance based on Guest model: A case study of Charmahal-Bakhtiari Gas distribution firm
}

\author{
Mashallah Valikhani Dehaghani $^{\mathrm{a}^{*}}$ and Mohamad Malekmohamadi Faradonbeh ${ }^{\mathrm{b}}$
}

${ }^{a}$ Assistant Professor, Dehaghan Branch, Islamic Azad University, Esfahan, Iran ${ }^{b}$ Department of Public Administration, Azad University of Dehaghan, Esfahan, Iran

\section{H R O N I C L E A B S T R A C T}

Article history:

Received October 14, 2012

Received in revised format

5 February 2012

Accepted 7 February 2013

Available online

February 72013

Keywords:

Human resource management

Guest model

Training system

Share ownership programs

Charmahal-Bakhtiari

\begin{abstract}
Human resource management plays an essential role on the success of any business units such as utility firms. In this paper, we present a study to investigate the effects of different human resource management on employee performance. The proposed study is applied on one of gas distribution units in province of Charmahal-Bakhtiari, which is located west part of Iran. There were 161 people working for this firm where 75 employees were working in center of province and 86 employees were working in other sides of province. Cronbach alpha is calculated as 0.83 , which is well above the minimum desirable limit. The study uses Pearson correlation test to investigate the effects of Hiring system, Training system, Job design, Organizational relationship and Share ownership programs on employee performance. The results of our survey indicate that job design is the most important technique for employee management followed by training system, organizational relationship and share ownership programs.
\end{abstract}

\section{Introduction}

Human resource management plays an essential role on the success of any business units such as utility firms (Guest, 1996; Guest, 2006; Guest, 2007). According to Guest (2002), there are two primary techniques to human resource management (HRM): one concentrating on the organizational concern for the relationship between HRM and performance and the other is to carefully mount a critique of HRM. Guest argued that both pay lip service to, but mostly neglect worker reactions to HRM. He recommended that worker attitudes and behavior mediate the HRM-performance relationship and that certain HR practices could be related to higher work and life satisfaction. These practices incorporate job design, direct participation and information provision, which are also associated with higher performance; but work satisfaction could be also related to equal opportunities, family-friendly and anti-harassment practices. Therefore, Guest explained that a more 
worker-friendly HRM could be used in the context of a partnership or mutual gains framework (Guest \& Hoque, 2007).

Guest (1994) presented an approach for HRM and explained how his method to HRM could draw heavily on the work of American organizational psychologists. He argued that people should take HRM seriously, but that, in the context of Europe, a rather various focus was necessary. Any change in HRM could impact productivity and efficiency of business units. According to McGregor et al. (2004) "changed employment relationships do not spell death to people development. Rather it makes managing talent different and more challenging”.

Sturges et al. (2005) studied the relationship between various kinds of career management activities, the psychological contract, and outcomes of psychological contract fulfillment. They examined a series of linked hypotheses to study the relationship between individual career management behavior with the experience of organizational career management help and looked to see whether it was associated with fulfillment of the psychological contract. They provided some support for these proposed links and made four contributions to the psychological contract and careers literature. First, it demonstrated that both individual and organizational career management behaviors were linked to psychological contract fulfillment. Second, organizational career management help could be related to affective commitment and job performance. Third, psychological contract fulfillment played an important role in mediating the relationship between career management help. Finally, organizational commitment could mediate between psychological contract fulfillment and individual career management behavior.

Kerfoot and Knights (2007) provided an in-depth case study of a UK mutual life insurance firm with the pseudonym Pensco. They examined changes in management practice, their influences on the nature of management control and the growth of self-discipline throughout the company's hierarchy. Focusing on two management methods associated with the development of team spirit among firm employees, they reported that these changes as coinciding with the emergence of a language, if not directly the practice, of HRM.

In this paper, we study the effect of different HRM techniques on employee performance. The organization of this paper first presents details of the proposed study in section 2 while section 3 presents the results of our survey. Finally, concluding remarks are given in the last to summarize the contribution of the paper.

\section{The proposed study}

Main hypothesis: There is a relationship between human resource management and employee performance.

There are five sub-hypothesis associated with the proposed study of this paper as follows,

1. There is a meaningful relationship between hiring method and employee performance measurement.

2. There is a meaningful relationship between training employee and performance measurement.

3. There is a meaningful relationship between designing appropriate job and performance measurement.

4. There is a meaningful relationship between organizational relationship and performance measurement.

5. There is a meaningful relationship between share ownership programs and performance measurement.

The proposed study of this paper is performed in one of Iranian gas distribution firms in province of Charmahal-Bakhtiari, which is located west part of Iran. There were 161 people working for this firm 
where 75 employees were working in center of province and 86 employees were working in other sides of province. The proposed study decided to use all employees' insight for the proposed study of this paper.

\section{The results}

In this section, we present details of our finding on relationship between performance measurement and other factors.

\subsection{The main hypothesis}

The main hypothesis of this survey studies the relationship between performance measurement and human resource management. Table 1 shows details of our finding on different questions we used to verify this hypothesis.

Table 1

The results of the survey on the components of the main hypothesis

\begin{tabular}{lcc}
\hline Employee performance perspectives & Pearson Correlation & Sig. \\
\hline Reliability & 0.47 & 0.000 \\
Attitude & 0.40 & 0.000 \\
Work quality & 0.19 & 0.020 \\
Heuristic approach & 0.37 & 0.000 \\
Judgment & 0.28 & 0.001 \\
Cooperation & 0.15 & 0.060 \\
Quantity of work & 0.18 & 0.02 \\
Security & 0.15 & 0.06 \\
Learning and development & 0.35 & 0.000 \\
Person & 0.30 & 0.000 \\
Leadership & 0.51 & 0.000 \\
\hline
\end{tabular}

As we can observe from the results of Table 1, expect one case, cooperation, all other components of Table 1 are meaningful when the level of significance is five percent. Therefore, we can conclude the main hypothesis of this survey has been confirmed.

\subsection{The first sub hypothesis: Hiring system and employee performance}

The first sub-hypothesis of this survey studies the relationship between the method of hiring employee and employee performance. Table 2 demonstrates the results of our survey,

\section{Table 2}

The results of the survey on the components of the first sub hypothesis

\begin{tabular}{lcc}
\hline Employee performance perspectives & Pearson Correlation & Sig. \\
\hline Hiring employee and performance measurement & 0.57 & 0.000 \\
Hiring employee and Reliability & 0.33 & 0.000 \\
Hiring employee and Attitude & 0.19 & 0.010 \\
Hiring employee and Work quality & 0.29 & 0.000 \\
Hiring employee and Heuristic approach & 0.45 & 0.000 \\
Hiring employee and Judgment & 0.34 & 0.001 \\
Hiring employee and Cooperation & 0.15 & 0.060 \\
Hiring employee and Quantity of work & 0.10 & 0.2 \\
Hiring employee and Security & 0.06 & 0.40 \\
Hiring employee and Learning and development & 0.55 & 0.000 \\
Hiring employee and Person & 0.44 & 0.000 \\
Hiring employee and Leadership & 0.56 & 0.000 \\
\hline
\end{tabular}


Based on the results of Table 2, except security, quantity of work and cooperation, all other components are statistically meaningful when the level of significance is five percent leading us to conclude that hiring technique positively influence employee performance, significantly. Therefore, we can conclude that firms with strong hiring methods are able to perform better than others are.

\subsection{The second sub hypothesis: Training system and employee performance}

The second sub-hypothesis of this survey studies the relationship between the method of hiring employee and employee performance. Table 3 demonstrates the results of our survey,

\section{Table 3}

The results of the survey on the components of the second sub hypothesis

\begin{tabular}{lcc}
\hline Employee performance perspectives & Pearson Correlation & Sig. \\
\hline Training employee and performance measurement & 0.41 & 0.000 \\
Training employee and Reliability & 0.18 & 0.02 \\
Training employee and Attitude & 0.41 & 0.01 \\
Training employee and Work quality & 0.52 & 0.000 \\
Training employee and Heuristic approach & 0.14 & 0.08 \\
Training employee and Judgment & 0.28 & 0.001 \\
Training employee and Cooperation & 0.19 & 0.020 \\
Training employee and Quantity of work & 0.08 & 0.3 \\
Training employee and Security & 0.02 & 0.70 \\
Training employee and Learning and development & 0.20 & 0.01 \\
\hline Training employee and Person & 0.43 & 0.000 \\
Training employee and Leadership & 0.33 & 0.000 \\
\hline
\end{tabular}

Based on the results of Table 3, except security and quantity of work, all other components are statistically meaningful when the level of significance is five percent leading us to conclude that training technique positively influence employee performance, significantly. Therefore, we can conclude that firms with strong training systems are able to perform better than others are.

\subsection{The third sub hypothesis: Job design and employee performance}

The third sub-hypothesis of this survey investigates the relationship between the method of hob design and employee performance. Table 4 shows the results of our survey,

\section{Table 4}

The results of the survey on the components of the third sub hypothesis

\begin{tabular}{lcc}
\hline Employee performance perspectives & Pearson Correlation & Sig. \\
\hline Job design and performance measurement & 0.53 & 0.000 \\
Job design and Reliability & 0.55 & 0.000 \\
Job design and Attitude & 0.42 & 0.000 \\
\hline Job design and Work quality & 0.17 & 0.04 \\
Job design and Heuristic approach & 0.44 & 0.000 \\
Job design and Judgment & 0.32 & 0.000 \\
Job design and Cooperation & 0.18 & 0.020 \\
Job design and Quantity of work & 0.21 & 0.009 \\
Job design and Security & 0.02 & 0.70 \\
Job design and Learning and development & 0.34 & 0.000 \\
Job design and Person & 0.12 & 0.01 \\
Job design and Leadership & 0.55 & 0.000 \\
\hline
\end{tabular}


Based on the results of Table 4, except security, all other components are statistically meaningful when the level of significance is five percent leading us to conclude that job design technique positively influences employee performance, significantly. Therefore, we can conclude that firms with good job systems are able to perform better than others are.

\subsection{The fourth sub hypothesis: Organizational relationship and employee performance}

The fourth sub-hypothesis of this survey investigates the relationship between organizational relationships and employee performance. Table 5 presents the results of our survey,

\section{Table 5}

The results of the survey on the components of the fourth sub hypothesis

\begin{tabular}{lcc}
\hline Employee performance perspectives & Pearson Correlation & Sig. \\
\hline Organizational relationship and performance measurement & 0.14 & 0.09 \\
Organizational relationship and Reliability & 0.10 & 0.2 \\
Organizational relationship and Attitude & -0.10 & 0.2 \\
Organizational relationship and Work quality & -0.20 & 0.01 \\
Organizational relationship and Heuristic approach & -0.11 & 0.1 \\
Organizational relationship and Judgment & -0.34 & 0.000 \\
Organizational relationship and Cooperation & 0.09 & 0.2 \\
Organizational relationship and Quantity of work & 0.11 & 0.8 \\
Organizational relationship and Security & 0.29 & 0.000 \\
Organizational relationship and Learning and development & 0.18 & 0.02 \\
Organizational relationship and Person & 0.32 & 0.6 \\
Organizational relationship and Leadership & 0.17 & 0.03 \\
\hline
\end{tabular}

Based on the results of Table 5, in most cases the results of Pearson correlation ratios are not statistically significance and we cannot conclude that organizational relationship could influence performance measurement. Therefore, the fourth sub-hypothesis is not confirmed.

\subsection{The fifth sub hypothesis: Share ownership programs and employee performance}

The fifth sub-hypothesis of this survey investigates the relationship between the Share ownership programs and employee performance. Table 6 presents the results of our survey,

\section{Table 6}

The results of the survey on the components of the fifth sub hypothesis

\begin{tabular}{lcc}
\hline Employee performance perspectives & Pearson Correlation & Sig. \\
\hline Share ownership programs and performance measurement & 0.04 & 0.50 \\
Share ownership programs and Reliability & 0.11 & 0.1 \\
Share ownership programs and Attitude & 0.23 & 0.005 \\
Share ownership programs and Work quality & 0.32 & 0.000 \\
Share ownership programs and Heuristic approach & 0.06 & 0.4 \\
Share ownership programs and Judgment & 0.13 & 0.1 \\
Share ownership programs and Cooperation & 0.01 & 0.80 \\
Share ownership programs and Quantity of work & 0.18 & 0.02 \\
Share ownership programs and Security & 0.08 & 0.2 \\
Share ownership programs and Learning and development & 0.03 & 0.60 \\
Share ownership programs and Person & 0.22 & 0.006 \\
Share ownership programs and Leadership & 0.22 & 0.006 \\
\hline
\end{tabular}


Based on the results of Table 5, in most cases, the results of Pearson correlation ratios are not statistically significance and we cannot conclude that organizational relationship could influence performance measurement. Therefore, the fifth sub-hypothesis is not confirmed.

\section{Conclusion}

In this paper, we have presented an empirical investigation to study the impact of different HRM techniques on employee performance. We have implemented Pearson correlation test to investigate the effects of Hiring system, Training system, Job design, Organizational relationship and Share ownership programs on employee performance. The results of our survey have indicated that job design is the most important technique for employee management followed by training system, organizational relationship and share ownership programs.

\section{Acknowledgment}

The authors would like to thank management of Gas distribution firm for cordially cooperating for the accomplishment of this paper.

\section{References}

Guest, D. E. (1994). Organizational psychology and human resource management: Towards a European approach. European Journal of Work and Organizational Psychology, 4(3), 251-270.

Guest, D. E. (1997). Human resource management and performance: a review and research agenda. International Journal of Human Resource Management, 8(3), 263-276.

Guest, D. (2002). Human resource management, corporate performance and employee wellbeing: Building the worker into HRM. Journal of Industrial Relations, 44(3), 335-358.

Guest, D. E. (2006). Human resource management-the workers' verdict. Human Resource Management Journal, 9(3), 5-25.

Guest, D. E. (2007). Human resource management and industrial relations. Journal of Management Studies, 24(5), 503-521.

Guest, D., \& Hoque, K. (2007). The Good, the Bad and the Ugly: Employment relations in new nonunion workplaces. Human Resource Management Journal, 5(1), 1-14.

Kerfoot, D., \& Knights, D. (2007). Planning for personnel? Human resource management reconsidered. Journal of Management Studies, 29(5), 651-668.

McGregor, J., Tweed, D., \& Pech, R. (2004). Human capital in the new economy: devil's bargain?. Journal of Intellectual Capital, 5(1), 153-164.

Sturges, J., Conway, N., Guest, D., \& Liefooghe, A. (2005). Managing the career deal: The psychological contract as a framework for understanding career management, organizational commitment and work behavior. Journal of Organizational Behavior, 26(7), 821-838. 